\title{
Russian in the multilingual environment of three Asian countries
}

\author{
Ekaterina PROTASSOVA ${ }^{1}$, Neelakshi SURYANARAYAN ${ }^{2}$ \\ and Maria YELENEVSKAYA ${ }^{3}$ \\ ${ }^{1}$ University of Helsinki \\ Helsinki, Finland \\ ${ }^{2}$ University of Delhi \\ Delhi, India \\ ${ }^{3}$ Technion-Israel Institute of Technology \\ Haifa, Israel
}

\begin{abstract}
This article provides a comparative analysis of the sociolinguistic situation in three Asian countries, India, Japan, and South Korea, which are relatively less known as countries where the Russian language is used. The aim of the study is to assess the significance of the Russian language in these countries' Russian-speaking diasporas, business sphere, and education, as well as to define the characteristics of its teaching in the cultural contexts under discussion. In all these domains processes of language commodification are intensifying. The countries chosen for analysis differ in the history of language contacts, political relations with Russia, language policy, language attitudes, and as a result, residents' motivation for maintaining and learning the Russian language. We discuss similarities and differences in the development of Russian speech communities. We also reflect upon linguistic and cultural hybridity, and in particular, its effect on the evolution of multilingual identities on the basis of interviews, fieldnotes, internet resources, and published data. The results show that in Japan and South Korea, the number of immigrants, students, businesspeople and mixed families using Russian is growing, and Russian language schools are popular; in India, the established relationship of peace, friendship and cooperation through various treaties continues to have its effect on the popularity of the Russian language in various spheres of life. In all the three countries Russian serves as a lingua franca for immigrants from different post-Soviet countries, which increases its value for the diasporans. The study argues that realities of diasporic life contribute to the pluricentric trends in the development of Russian.
\end{abstract}

Keywords: Russian language migrants, pluricentrism (pluricentricity), Russian-speaking diaspora, Russian language maintenance abroad, multilingualism

\section{For citation:}

Protassova, Ekaterina, Neelakshi Suryanarayan and Maria Yelenevskaya. 2021. Russian in the multilingual environment of three Asian countries. Russian Journal of Linguistics 25 (4). 981-1003. https://doi.org/10.22363/2687-0088-2021-25-4-981-1003 
Научная статья

\title{
Русский язык \\ в многоязычной среде трех стран Азии \\ Екатерина ПРОТАСОВАํㅜ, Нилакши СУРЬЯНАРАЯН ${ }^{2}$, Мария ЕЛЕНЕВСКАЯ ${ }^{3}$ \\ ${ }^{1}$ Хельсинкский университет \\ Хельсинки, Финляндия \\ ${ }^{2}$ Делийский университет \\ Дели, Индия \\ ${ }^{3}$ Технион - Политехнический Институт \\ Хайфа, Израиль
}

\begin{abstract}
Аннотация
В статье рассматривается социолингвистическая ситуация в трех странах Азии - Индии, Японии и Южной Корее, которые известны сравнительно меньше в качестве стран, где используется русский язык. Цель исследования - определить роль русского языка в русскоязычных диаспорах данных стран, в деловой сфере и образовании, а также выявить особенности его преподавания в рассматриваемых культурных контекстах. В странах, отобранных для анализа, по-разному складывались языковые контакты с русским языком, политические отношения с Россией, языковая политика, языковые установки, соответственно, и мотивация к сохранению и изучению русского языка у них разная. Мы рассматриваем сходства и различия в развитии русскоязычных сообществ в трех странах и обсуждаем явления языковой и культурной гибридности и, в частности, их влияние на идентичность многоязычной личности, основываясь на интервью, полевых записях, интернет-ресурсах и опубликованных данных. Результаты свидетельствуют о том, что в Японии и Корее растет количество иммигрантов, студентов, предпринимателей и членов смешанных семей, пользующихся русским в повседневной жизни, а русские школы и образовательные центры приобрели большую популярность. В Индии давние отношения дружбы и сотрудничества с Россией, поддерживаемые двусторонними соглашениями, способствуют популярности русского языка в различных сферах жизни. Во всех трех странах русский язык служит как лингва-франка для иммигрантов из разных постсоветских стран, что повышает его ценность для представителей диаспор. В исследовании утверждается, что реалии жизни в диаспоре способствуют плюрицентрическим тенденциям в развитии русского языка.
\end{abstract}

Ключевые слова: русскоязычные мигранты, плюрицентризм (плюрицентричность), русскоязычная диаспора, сохранение русского языка за рубежом, многоязычие

\section{Для цитирования:}

Protassova E., Suryanarayan N., Yelenevskaya M. Russian in the multilingual environment of three Asian countries. Russian Journal of Linguistics. 2021. Vol. 25. № 4. P. 981-1003. https://doi.org/10.22363/2687-0088-2021-25-4-981-1003

\section{Introduction}

The discussion of the role and essence of pluricentric languages closely interacts with the concepts of norm / standard / variant, as well as the (non-)native speaker, diaspora, and transnational community (Kloss 1952, Clyne 1992). We claim that the role of Russian as a second language and as a lingua franca is to some extent similar to that of English in the expanding circle (cf. Proshina \& Nelson 
2020). At the same time, the necessity for a common language serving different speech communities is growing stronger, which does not exclude the need to speak and write languages used locally.

Russian today can also be considered a language with different circles of use, in other words, a pluricentric language. This article follows up on our previous work on pluricentric tendencies in the development of the Russian language (Mustajoki \& Protassova 2004, Mustajoki et al. 2010, 2019, Nikunlassi \& Protassova 2014, 2019, Yelenevskaya \& Protassova 2015, Suryanarayan 2017a, 2017b). This approach to language studies combines analyses of linguistic phenomena with research into socio-political, ideological and economic conditions that make the use of a language beneficial for groups residing far from the center where the dominant variety rules. We started studying the modes of Russian language use in a number of countries (e.g., Protassova \& Yelenevskaya 2021, Protassova et al. 2020) and we continue applying the pluricentric lens to its forms and functions in three Asian countries, India, Japan and South Korea, where the number of Russian speakers has increased thanks to recent immigration and enhanced tourism (Rosstat 2019, Emigrating 2020). In multilingual communities, languages adapt to the conditions of communication, to linguistic diversity and superdiversity, and hardly any speakers remain monolingual (Pavlenko 2008, Oglezneva 2009, Rovinskaya 2013, Gasparov \& Kupina 2014, Ryazanova-Clarke 2014). This means that although multiple varieties can be called regional variants of Russian and cannot be mixed up under the same label, such as "diasporic Russian," yet, they are used in similar communities of practice and shape each other through contact and mutual adaptation.

We will discuss in what domains Russian is used in the three countries in Asia and how it is evolving. Each section devoted to one of the three countries under study

- gives a brief overview of the history of Russian language use there;

- examines the reasons for Russian-language maintenance and speakers' attitudes to the sociolinguistic situation in their community;

- looks at domains in which Russian is used;

- outlines the nature of deviations from the language norm as viewed in Russia.

Material for the article has been drawn from interviews with L1, L2 and L3 speakers of Russian in respective countries conducted at different times and at different places. All of them were audio-recorded, parts relevant for the research projects were transcribed and subjected to analysis. Our other sources are electronic media and 35 Internet discussion forums (for the sake of anonymity and space economy, we are not giving the names of the participants). Finally, we studied scholarly literature devoted to the history and functioning of the Russian language in the countries discussed, and conducted ethnographic diaries recording informal conversations with lay people and researchers from the countries we studied. In other words, we used both existing and researcher-generated data (Rapley 
2007: 10). So, data collection and analysis continued as a cycle throughout the entire research process (Corbin \& Strauss 2015: 3-17).

In order to give a sociolinguistic background of the use of Russian in India, Japan and South Korea and outline regional deviations from Russia's Russian, we applied a mixed methodology. Its main components are the sociolinguistic method of document analysis, text analysis and participant and non-participant observation (Bowen 2009: 27). We used text analysis paying special attention to the topics raised, instances of translanguaging, innovative forms, deviating from the norm as it is viewed in Russia, and to the contextual clues which help to interpret the overall sense of communication, be it an interview or a forum discussion. As interviewers, participants in forum discussions, and interlocutors in face-to-face informal conversations with colleagues and clients in various immigrants' establishments, we conducted participant observation. Sometimes we acted as lurkers in public discussion groups, doing non-participant observation, and both types were recorded in our ethnographic diaries. Thus, triangulation and multimethod approach allowed us to look at the topic of our research from different perspectives.

\section{Russian in India}

The relations between India and Russia are extremely multifaceted and versatile (cf. Rishi 1982, Shlapentokh 2012, Kuhrt \& Kiseleva 2017, Burgess 2019). Barman (2015) mentions the Russian mission in Mumbai, formerly Bombay, which in the $19^{\text {th }}$ century promoted the knowledge of Russian among Indian officials. According to Dey (2015) and Thakur (2017), the first encounters and mutual interests of Indians and Russians were on the Silk Road, yet the study of Russian started only in the 1940s, first in Calcutta (Kolkata), then in Delhi and Allahabad. Periods of interest in Russia and its culture alternated with times of indifference. The Soviet Union was one of the first countries to recognize the independent India and thereafter, Russian language teaching commenced in various universities and centers of multilingual and multicultural India. There was a need to equip Indian personnel with the language skills so that they could work in the big and small industrial projects undertaken in India with the help of the Soviet Union. Gradually, Indians of various professions realized the importance of learning the language - army and naval officers, engineers, businessmen and even shopkeepers and traders so that they could communicate effectively with the Russian speakers visiting India either to work or as tourists (Sahai 1990).

Today Russian is taught at various levels, from school to postgraduate programs, and at dozens of universities. Scholars doing research in the Russian language and culture publish internationally and also in the Indian journals "Russian Philology", "Critic", "Resonance" and "Assonance", which appear regularly. There are also numerous centers of Russian Science and Culture which conduct language and cultural projects involving people studying Russian for professional purposes and those who learn Russian for personal enrichment. Some centers organize language lessons and various courses in Russian for the Russian- 
speaking children of expats and those growing up in mixed families. Many of the Indian experts studied in the Soviet Union and post-Soviet Russia, and as the need to know Russian remains relatively high, their professional skills are in demand.

A large number of students from various parts of India who went to the Soviet Union / Russia from the 1960's onwards to obtain higher education in the fields as diverse as medicine, engineering, sciences, cinematography, philology, etc., constitute another group of people who speak Russian and continue to converse in the language as and when the opportunity arises (social gatherings of alumni associations, functions organized by the Russian Embassy and Russian Centers of Science and Culture, etc.).

Therefore, presently, Indian citizens who speak Russian to varying degrees are graduates of Russian universities, students of different part-time courses run by the Russian government-sponsored Russian Centers of Science and Culture in the cities of Chennai and Trivandrum (south India), Mumbai (west India), Kolkata (east India) and Delhi (central India), as well as students who study Russian at Indian universities and other educational institutions (including some secondary schools). The approximate number is estimated at several tens of thousands of people, though it is difficult to provide exact numbers (Arefyev 2012: 301-303). There is a large segment of people in service industries using Russian: shopkeepers, yoga instructors, tourist guides and others who have picked up Russian 'on the job.' Their proficiency is limited and is just enough to suit their commercial needs (Suryanarayan 2017a). Similarly, a considerable workforce with knowledge of Russian is engaged by hospitals to help with language needs of patients coming from Russia and the CIS countries for medical treatment (Suryanarayan 2017b, Muth \& Suryanarayan 2020). For all of these, Russian is a foreign language and the level of knowledge is mixed, from very fluent and excellent to medium to limited.

Another and probably more interesting group of Russian-speaking people that should be studied is the Russian diaspora and the changing use of their native language in alien settings. Russian diasporans have made different parts of India their home. Many are members of mixed families, determined students seeking to perfect their skills in Indian classical dance, yoga and Ayurveda practices. Some are employees of local business firms and banks, freelancers, residents at ashrams and the Auroville community (Pondicherry) and other abodes in the Himalayan mountain range (Mcleodganj - residence of the Dalai Lama). Diasporans continue to preserve their language and culture and are keen on passing on the Russian legacy to their children. The government-sponsored Russian Cultural Center in Delhi organizes various events for the expatriates. In addition, large groups have formed their own associations and try to preserve the Russian language, culture, and festive traditions in informal settings. Their children are taught Russian either at home or at the Russian Cultural Centers. As mentioned earlier, their Russian is influenced by Hindi and Hinglish, which can be observed at the phonetic and lexical levels, as well as in semantic usage and style.

A research project based on questionnaires and interviews with a few mixed families residing in Delhi and its nearby areas aimed to determine the influence of 
the local language and culture on the way Russian is spoken by the diasporans. The project revealed frequent code mixing and translanguaging. One participant, a lady in her mid-forties, said that her Russian mother insisted on speaking to her only in Russian at home, so she grew up in a trilingual environment, speaking English, her father's language Hindi, and her mother's native Russian. We observed her continuously mixing these languages in conversations with her mother. Her mix of languages could be intriguing for an outsider: Да, да, я делала дхаду утром (дхаду лагана 'to sweep the floor'). In this construction the speaker is conveying the action of sweeping the floor which in the Hindi language is conveyed by the expression 'to apply the broom' without indicating the place, by using the Russian verb делать (to do) with the Hindi noun дхаду 'broom.'

In another expression я гундую атта, the speaker applies the Russian ending of the first person singular to the Hindi verb гундна 'to knead' and adds the object amma 'dough' without changing the ending. This is a comfortable use of the Russian verb ending, since the Hindi expression for kneading the dough (an exercise carried out daily in Indian households to make fresh chapattis) is far too long (мейн атта гунд рахи хун). A similar pattern is applied in the past tense, and the blending of Hindi and Russian also indicates the gender: я уже гундала атта. The speaker says she does not change the feminine ending according to the rules of Russian grammar because she follows the rules applicable to Hindi.

In other instances, many of the expatriates interviewed said that they inserted English expressions ok, fine, good, great, super and Hindi expressions accha 'good, ok', bahut accha 'very good', theek hai 'fine, ok' in their sentences when speaking Russian. For example: Сегодня наш обед в ресторане был просто great! or Давай пойдём сегодня в кино? - Theek hai, пойдём! Another Hindi expression Jaldi jaldi 'quickly' was found to be used rather frequently by Russian mothers when conversing with their children: Давай, делай домашнее задание джалди, джалди; Надо выучить стихотворение джалди, джалди. Mixing names of food items is a prominent area of code mixing, even where the names are not specifically local. For example: Дай мне ложку чини! (sugar). Я хочу пани 'water': Я хочу нимбу пани 'lemon water', Ть хочешь чай with дудx 'milk' или without? Давай сегодня приготовим чавал 'rice' u chicken. In these particular cases there is use of both English and Hindi.

Some of the mothers expressed their concern that their children were unable to pronounce the Russian sounds according to the phonetic norms, the most prominent problem being the Russian hard L. Other phonetic errors or mispronunciations observed by the mothers are related to the wrong word stress and unconventional prosody.

The above examples give us a glimpse of how Russian expatriate families living in and around Delhi manipulate their language repertoire to suit their pragmatic needs. This trend is more visible in the second generation of the expats, but our study was limited to a few families of the first generation, except in the first case, where the respondent is already a second-generation adult. As can be seen 
from the examples cited, this phenomenon is most prominent in colloquial and day to day language spoken around the house or amongst friends. Further research expanding to other parts of India and amongst other social categories should reveal more interesting instances of the fascinating use of the Russian language in different settings and with different constellation of languages amongst Russian-speaking expatriates.

Indians studying Russian as a foreign language face their own challenges at the level of phonetics, morphology, semantics and expression of culture-specific values. Suryanarayan (2014) points out that the most typical errors of the Indian students in Russian are interference with English and local languages. In the Russian-language pedagogy the professional skills sought after by organizers of education are computer-based teaching, collaborative learning which boosts motivation at different levels, and modern Russian language and literature (Saini 2017). There is still a dearth of teaching materials using cutting-edge methods. Coursebooks for students learning Russian in India should be communicatively and practically oriented and brought closer to present-day realities and young people's interests (Sunita et al. 2012). Indian teachers of Russian are actively involved in writing textbooks and other teaching manuals taking into account specific needs of the Indian students and the requirements of the present-day labor markets. A lot is being done by Indian teachers independently and in collaboration with Russian colleagues to maintain a high level of teaching Russian. This is a topic of fruitful discussions amongst researchers and instructors.

\section{Russian in Japan}

The history of Russian-Japanese relations is full of ups and downs. Early Russian overtures towards Japan date back to the $1600-1850$ period (Wells 2004, Lim 2013). This was the time when Japan was still maintaining its international isolation policy (JASRLL). The first phase saw various private initiatives, while governmental relations started only in the mid- $19^{\text {th }}$ century with the signing of the Shimoda Treaty in 1855 (Lensen 1954). Due to increasing contacts with the Russian Empire in the northern region and demand for Russian language professionals, a few Japanese-Dutch interpreters working for the Edo Shogunate were assigned to learn the language. Among the first teachers of Russian was a Japanese castaway, Kodayu Daikokuya, who returned to Japan after living in Russia for almost a decade, and a Russian navigator, vice-admiral, Vasily Golovnin who was seized and held captive in Japan for two years (JASRLL 2000). In the age of information technology, it is not easy to imagine how teachers and learners tackled their Russian language studies with neither dictionaries nor teaching materials available.

In the mid-1850s, after decades of negotiations, the two countries finally signed three treaties and officially established diplomatic and commercial relations (JSSRH 1993). In 1857, the first Russian Imperial consulate was established in the city of Hakodate and Russian government officials, merchants, and Russian Orthodox priests began to settle in major cities, including Nagasaki, Kobe, Kyoto, 
Tokyo and Sapporo (Khisamutdinov 2013). They started their own businesses, built hotels, restaurants, and cathedrals. It was in Hakodate that the first Russian primer and journal were published. The Russian Orthodox Church became one of the symbols of the town. The rich tradition of publishing in Russian still continues today. The mutual cultural interest has always been high (Mikhailova \& Steele 2008, Baxter 2009) despite serious political controversies (e.g., Kuhrt 2007, 2015, Kuroiwa 2011).

Transmission of the Russian language to children and teaching it to Japanese people has always been at the center of publishers' work (Pajchadze 2008). According to Khisamutdinov (2013), Nagasaki, Sapporo, Kobe, Kyoto and Tokyo were at the crossroads of Russian-American interests in Asia. Big cities have Russian Orthodox churches, and one finds a variety of artefacts witnessing the Russian presence in Japan. Hokkaido is a frequent destination for Russian tourists who come to thermal water resorts and support this region economically; many signs in public places are in Russian, and Russian-speaking guides offer their services. Different monuments mark places where Russian ships sank, and the local people still remember stories about seamen who met their death there. Fishermen in both countries cooperate and compete. Japanese citizens born on the Kuril Islands and Sakhalin come to their birthplaces to visit family graves.

Russian and Soviet relationships with Japan in the past were not devoid of aggression, yet awareness of mutual interests is still reflected in the attitudes of the Japanese to Russia (e.g., Sindzi 2005, Konishi 2013). Nagatsuka (2014, 2017) collected items and stories attesting to the great influence of Russian culture on Japan and vice versa. This influence was multilayered and versatile, ranging from food and clothes to science and politics. Russian literature and music are still popular in Japan, and many universities offer courses in Russian (Yamasita 2010, Kidera 2017). In the post-Soviet period Russians have launched many new businesses, the main trades being timber, seafood, cars, and tourism. The Japanese are interested in Russian art and nature and like to see documentaries about them, while Russians are fond of and mystified by the Japanese way of life and buy products that have no analogies in their own country (Musaev \& Tojama 2014).

The previous waves of Russian immigration contributed to the cultural life of Japan (Podalko 2019). However, many Russian émigrés left Japan and reimmigrated to the U.S.A. or Australia (Savada 1999). Some Russian speakers are Koreans from Sakhalin who are descendants of those families that settled on the island when it belonged to Japan. Thanks to the loosening of emigration and immigration rules and the increased mobility of Russian citizens, the post-Soviet diaspora in Japan is rapidly growing (Nikiporec 2007, Nikiporec-Takigava 2007, 2011). Golovina $(2018,2019)$ studied the material and living culture of the Russianspeaking people in Japan and found that some objects in immigrants' homes trigger emotions such as nostalgia, sentimentality, and commonality with their preimmigration life while others are markers of their changing tastes and identities. In fact, materiality of the Russian immigrants' homes reveals transformative 
experiences of migration and integration processes. Japanese-Russian relations are being promoted more than ever before in the domains of politics, economics and culture, both on the governmental and on the individual level (see, e.g., numerous Ru.net forums and blogs in which Russian speakers living in Japan share their knowledge and perception of the Japanese people and their way of life with their co-ethnics and reflect on the differences between the two countries: ENA, May 20, $2021)^{1}$. Numerous discussions show that Russian internet users are also curious to know how the Japanese perceive Russia. Some "old-timers" summarize their own experiences of socializing in Japan, others give the floor to the Japanese people themselves (ENA, May 20, 2021) ${ }^{2}$. Although some posts reproduce familiar ethnic stereotypes, others honestly try to understand their neighbors better.

Due to compact settlement (the majority live in big cities), the speech of newcomers from Russia shows signs of an evolving ethnolect: they employ Japanese borrowings and calques in their everyday communication. Kazakevich (2013) summarized typical cases of translanguaging of Russian speakers: they use Japanese insertions denoting culinary dishes, household objects, as well as names of institutions and documents, and work- and education-related terminology. Japanese words are used in talk about weather, flora and fauna, and various natural phenomena. Most of the Japanese insertions in the diasporans' speech are names of objects and phenomena absent or semantically different in Russian, or just very frequent in Japanese. In addition, since many green horns have questions concerning their legal status and relations with various state agencies, there are numerous insertions from this domain. Here are some examples illustrating this: срок действия май Намба кадо, она по сроку привязана к зайрю, вписаны в джуминхйо на какую то дату, Джюминхе это типо регистраиия по месту жительства, сходите на бесплатный содан в куякусе еtc. Most of the Japanese insertions are transliterated in Cyrillic and appear as exoticism without being integrated into the Russian morphosyntactic system; some users insert hieroglyphs. A noticeable feature of communication is abundance of English words and expressions (cf. Hino 2020).

Peculiarities of Russian in Japanese learners' speech are similar to those of heritage speakers. The difference of the writing systems triggers a specific class of mistakes. Since there is no capitalization and since the borders between the words do not always correspond to the hieroglyphs, spacing between Russian words is violated. Moreover, since hieroglyphs are written vertically, handwritten text looks strange as the letters are vertical rather than cursive. The softness is marked by $\mathbf{b}$, letters are confused because of the wrong identification of phonemes (labials, sonors and affricates). Russian language learners have difficulties with agreement,

$1 \mathrm{https} / / / \mathrm{vk} . c o m /$ russian.japan, facebook.com/groups/RSCIJ/members/ (accessed 18 November 2021).

${ }^{2} \mathrm{https} / / /$ pikabu.ru/story/chem_russkie_udivlyayut_yapontsev_3525182, https://republic.ru/posts/ 33096, http://www.aikido-tatami.ru/about/art/art_35.html, https://www.factroom.ru/obshchestvo/ japan-russia (accessed 18 November 2021). 
declension, affixation, verbs of motion, and interpretation of polysemic words. In Japanese, there are no prepositions, and parts of speech are classified differently. Russian speakers living in Japan have to adjust their way of life to the local realities, and borrow Japanese words to render concepts reflecting life in Japan. Thus, mothers discuss their children's education using the words eiken, the English exam; $d z j u k u$, maths+society+Japanese, a system of private schools for additional education; jobiko, additional education; bukacu, after-school activities; ikudzi, an educational system. Russian speakers borrow not only names of shops, brands, restaurants, places, but also concepts: amaeru 'mother love for the child' (cf. Kirichenko 2020).

Although more often a minor than a major discipline, Russian was and is taught at many Japanese universities, as it opens doors to the Russian Far East and Central Asia (Avakiants 1995, Nakamura 2003). Teachers use materials written both in Japan and in Russia, and there is even a Japanese Society for Russian Language Education, which regularly issues a journal (ENA, May 20, 2021) ${ }^{3}$. The new direction in language pedagogy is the teaching of Russian to children in bilingual Japanese-Russian families (Sivakova 2009, Russistics in Japan 2016). Teachers focus on specific difficulties connected to the differences in writing systems of the two contact languages, text structure, conversation formulas, and other ethnicityoriented features of literacy. One of the best known experts is Daria Kumatrenko who teaches in the Rosinka school in Tokyo and whose blog is read by thousands of Russian-speaking parents throughout the world. Shatokhina (2012) has enumerated institutions that organize teaching for Russian-speaking children and the results of her survey show that although most of the children attending these schools and centers possess two passports, only $86.3 \%$ have had an opportunity to visit Russia. Parents want their children to learn Russian in order to speak to their family members in Russia and other Russian-speaking persons. They also hope Russian proficiency will be a boon in their future careers because bi-national collaboration is developing very rapidly in all domains of science, sports and culture. Most parents prefer to teach children at home; some apply to the Russian school at the embassy, but there are also those who attend private schools or hire private tutors. Fourteen per cent of the children do not study Russian at all, but their parents tend to let them watch Russian cartoons, even though $36.0 \%$ of the Russianspeaking families surveyed do not have access to Russian TV at home. Numerous schools, parishes, clubs and language centers offer tailored courses of Russian. Some Japanese schools, private and state universities, language centers and Russian-Japanese societies organize Russian teaching. Most children have friendships with Russian-speaking peers but 9.0\% demonstrate alienation from the things Russian and do not want to listen to songs, and radio programs or read literature in Russian. Assessing their children's Russian proficiency, most parents claim that their children can communicate in Russian without any problems (Shatokhina 2012, Pajchadze et al. 2021).

${ }^{3}$ https://rokyoken.web.fc2.com (accessed 18 November 2021). 


\section{Russian in South Korea}

For a long time, everything connected to the Russian language and culture was ignored or even forbidden, yet Russian could be studied at the Hankuk University of Foreign Studies since 1954, and later, at three more universities. Russian émigrés were employed as teachers enjoying the privileges of native speakers. There were not many job opportunities for alumni, but the 1988 Olympic Games in Seoul changed the field. Prior to this, Russian was studied mostly as a key to understanding what was happening in North Korea, because the USSR had a historical influence on that country. It supported the North Korean army during the war of 1950 - 1953, and after the war a large number of construction projects were funded by the Soviet Union. North Korea sent students to study at Soviet universities in Russian. Life in North Korea was covered in the Soviet mass media. Thanks to the propaganda the Soviet public had a positive image of North Korea which was reinforced by brief and superficial exposure to the North Korean realities during tourist visits. At the same time South Korea had the image of a hostile and militarist regime (Bazhanov \& Bazhanova 1991, Kim 2012, Min et al. 2018). In 1990, diplomatic relations between Russia and South Korea were established. Although hopes for quick economic benefits expressed at the beginning of the 1990s failed, some expectations were gradually fulfilled, e.g., Samsung, LG, Hyundai, and Kia's trade cooperation with Russia. South Korea is becoming increasingly important in the Russian plans to develop the Far East which can benefit from the Korean New Northern Policy (Hoon 1993, Rinna 2019). Today, teaching Russian in South Korea has already become a tradition; it is studied at about 40 universities and ranks among popular foreign languages. Guest teachers from Russia widely use authentic materials, and Korean students come to Russian universities to practice the language or take a semester in the Russian-language academic medium. Most of the teachers and lecturers speak of specific difficulties connected with differences in cultures and the educational traditions of the Korean and European students that make the process of learning very different from what Koreans are used to (Ballod 2009, Deponian 2015).

The growing popularity of the Russian language lets members of the returning diaspora use their proficiency in Russian to teach the language. We can find many of them advertising tutoring in Russian on the Internet. Some of the advertisements are in Russian only, others in Russian and Korean, still others use English. Not all those who are willing to teach Russian have appropriate qualifications, but everyone mentions the number of years spent in Russia as proof of their proficiency. It is also customary to mention the teacher's proficiency in the Korean language, an easy-going personality and a friendly and supportive attitude to students (ENA, May 20, 2021) ${ }^{4}$.

There are about 80,000 people speaking Russian on a daily basis, and nearly 50,000 of these are ethnic Koreans (many originally from Sakhalin). The number

\footnotetext{
${ }^{4}$ bulgomedu.com/teacher/teacher.asp?CateCode1=3\&CateCode2=1 (accessed 18 November 2021).
} 
of mixed marriages is growing, and more than 100 children are born every year in such families. There are many pre-primary schools operating in Russian or bilingually. More than a dozen Russian schools were launched in the post-Soviet period and their graduation certificates entitle young people to enter Korean universities. Founded in 2002, the Russian Embassy school in Seoul combines three languages (Russian, Korean and English), and the Russian school in Pusan that belongs to the Ministry of Education of Kazakhstan teaches several subjects in Russian. Lyceum TriLC in Seoul, a private school founded in 2009, offers blended teaching, combining contact and distance learning with four languages taught Korean, English, Russian, and German. In Seoul, Russian-speaking repatriates and immigrants created jobs and businesses serving the immigrant community and the hosts. The ethnic composition of the Russian speech community is diverse, including ethnic Koreans, people who emigrated from Central Asian states and Russian Far East, and from other CIS countries, as well as seamen. Joint festivities allow all those who know Russian, including Korean university students, to socialize together (Based on the information from the special issue Russistics in South Korea 2016.)

The Russian writer and traveler Nikolai Garin-Mikhailovsky (1852-1906) is a true genius loci of Korea. He collected Korean folklore and his work is still valuable for experts. The Russian Orthodox mission in Korea was founded at the end of the 19th century for the spiritual needs of 120 Russians and 30 Orthodox Koreans. The centrally located St. Nikolai Cathedral and other buildings around it rose at the beginning of the $20^{\text {th }}$ century. Religious books were translated into Korean. The Russian influence diminished and grew again several times, and many other cathedrals opened their doors to believers. There is a historical cemetery for foreigners called Yanhvadzhin with several Russian graves, mostly of sailors, and in Inchon there is a monument to those who died on the cruiser Varyag, erected in 2004 by the Russian government.

The Koryo-saram, or ethnic Koreans from the former Soviet Union, number half a million people and were dispersed mostly in Russia, predominantly in the Far East, but also in the Volgograd region and the Caucasus, Kazakhstan, Uzbekistan, and Ukraine. The Sakhalin Koreans form a separate community because they escaped later than the others. The history of the Russian Koreans was meticulously studied by Park (2018). Until recently, it remained obscure and infrequently discussed in Russia as Koreans were among the peoples displaced under Stalin. Kazakhstan was among the destinations where Koreans were exiled. In the then capital city of Almaty, Koreans had a newspaper and a theater. In addition, they bonded with the so-called "European population" rather than with the Turkicspeaking people, feeling closer to them in rituals, clothing, educational values and work ethics. Such prominent persons of Korean origin as Yulij Kim, Viktor Coj and Kostja Czju belong to the Russian cultural elite. After the collapse of the Soviet Union, there was no return program for Soviet Koreans, but with the borders opened, the influx started, followed by cheap labor forces from the CIS countries. 
Since Russian Koreans originate mostly from the Northern territories of Korea, they feel rather alien in the South. Besides the returning diaspora, other Russianspeaking migrants are qualified workers, businesspeople, and students allowed to study and later stay in Korea (Korgun 2014).

In the part of Seoul close to the Dongdaemun History and Culture Park metro station, there is a complex of blocks with numerous Russian-language inscriptions. This district founded in the 1990s by entrepreneurs from Khabarovsk and Vladivostok is abundant in shops and services operating in Russian (ENA, May 20, $2021)^{5}$. Like elsewhere in the world where the Russian language is exotic, these businesses serve those who would like to extract important information from advertisements, need to buy mobile phone cards and tickets, get internet connection, take credit, send remittances home, use a post office to send / receive documents and gifts, and so on. Businesspeople have small but comfortable hotels to stay in, and many texts on various signs are addressed to people from Uzbekistan, Kyrgyzstan and Kazakhstan whose lingua franca is regionally colored Russian. There are local shops and restaurants for this clientele, too. Signboards like Tovary narodnogo potreblenija [Goods for people's consumption] are tribute to the owners' and clients' nostalgia for Soviet past. Like in other countries where Russian-speaking diasporans open businesses, many bear the names of their owners: Tamara, Valentina or Yura, to name just a few. South Korean medical care is very popular in Central Asia, and medical tourism is booming, providing jobs for language professionals and proficient bi- and multilinguals who can act as interpreters and intermediaries. Car spare parts sale and cargo transportation are among the popular businesses. A mix of global and local brands offered in the cheapest price range attracts buyers. Russian-speaking visitors can use immigration and translation services, learn Korean, and get help in property acquisition. The Cyrillic script is also used for the Korean language as a marker of the presence of Koryo-saram who are not used to Korean and Chinese alphabets but can speak Korean. Moreover, Kyrgyz and Uzbek are also often transliterated in Cyrillic. Some Mongolian immigrants stay close to this diverse community. Besides Seoul, Tegu and Tedjon, maritime tourist destinations attract many Russian-speaking groups.

Koreans who study Russian have to overcome specific phonetic and grammatical difficulties. They confound $O$ and $Y, J$ and $P$, labials, sonors, sibilants, and often put stress on the wrong syllables. In Korean, there are no pluralia and singilaria tantum, all the words can be singular and plural, so learners have trouble using this category correctly in Russian. Elliptical sentences are not typical and hardly understandable. A lot of words denoting cultural phenomena and concepts are not translatable and require explanations (Russistics in South Korea 2016).

In everyday communication, Russian speakers borrow names of foods, dishes and spices, such as mivonom, yangmi, chibi, kjatamuri, drinks and other culinary terms and culture-specific words. They have to learn how to address people who are older or younger than them and distinguish between gendered forms (oppa,

\footnotetext{
${ }^{5}$ https://puerrtto.livejournal.com/919732.html (accessed 18 November 2021).
} 
onni, etc.), interjections (aigu, kichadi, omo). For young people recognizing and using slang appropriately is also important. The number of internet sites advertising online courses of the Korean language for beginners (see e.g., ENA, May 20, $2021^{6}$ and ENA, May 20, 20217) as well as lists of "the most frequent" words and expressions, ranging from 7 to 400 words, suggest high popularity of the Korean language and Korean culture among Russian speakers. Most of them are supplied with Korean words in Cyrillic transliteration and translation into Russian (ENA, May 20, $2021^{8}$, ENA, May 20, 2021 $1^{9}$ ). Some of these target tourists, but others are compiled for those who wish to come to Korea to study or work. The authors selected the "most useful words" relying on their own intuition and experience of living in Korea. Russian translations of these lists abound in spelling mistakes and use of non-standard grammar.

Internet sites maintained by Russian-speaking residents of South Korea and those who are planning to come to the country as guest-workers insert Korean words related to jobs and legal procedures in obtaining appropriate visas and work permits and dealing with employers: чонсо [cleaning], саджан [employer], гымм [gold]. The words most often used in this discourse acquire affixes and flexions: требуется петенщик, я работал пулпопом, требуются альпомщики, etc. Communicants distinguish themselves from the local population and perceive members of the host society as an outgroup, referring to them as хангуки, хангучки, often with pejorative connotations. Among forum participants there are many people from the countries of Central Asia and Ukraine. Although Russian is the lingua franca, it is not uncommon that participants insert phrases in their languages, e.g., in Uzbek, without other participants being offended. One can observe the same type of deviations from standard Russian as mentioned earlier. Some users resort to fake Ukrainisms as a sort of banter. Online chats abound in English insertions, although at least some of them are affected by Koreanized versions of the original words, e.g., проживание в апатах, хороший ванрум. Another frequent word is the German noun 'work': требуются на постоянный арбайт, приглашаем на арбайm. This is an indirect borrowing that came to Russian from the Korean advertising discourse.

At present, there is no traditional Russian-speaking society besides the Orthodox Church, which operates mostly in Korean. Yet, the influence of Korean on the Russian language is clear in the bilingual children and those ethnic Koreans who spoke Korean before returning to Korea. Despite some periods of confrontation, the general opinion about Russia and its policies among Koreans is quite positive (Lan'kov 2016).

\footnotetext{
${ }^{6} \mathrm{https} / / /$ lingust.ru/korean (accessed 18 November 2021).

${ }^{7} \mathrm{https}: / /$ www.hangugo.ru/ (accessed 18 November 2021).

${ }^{8} \mathrm{https} / / /$ kitsunestudy.ru/frazy-na-korejskom-jazyke-kotorye-prigodjatsja-v-puteshestvii/ (accessed 18 November 2021).

${ }^{9}$ https://koreasimple.com/50_samyh_chasto_ispolzuemih_slov/ (accessed 18 November 2021).
} 


\section{Discussion}

The three countries considered in this article have different histories of contacts with the Russian language and culture. Yet, there are many similarities between them regarding the motives for language maintenance. These are transnational families, friendly and business relations, and preservation of intergenerational ties. Importantly, in all the countries discussed, Russian still functions as the lingua franca for people born in different parts of the FSU. People using a lingua franca are commonly more tolerant of deviations from the dominant norm, yet there are always people in these communities who "police" participants, pointing to mistakes and sometimes ridiculing them. Clearly, common innovations occur in those aspects of the Russian language which often confuse native speakers and which exemplify irregularities, i.e. in "weak areas of the system" as Glovinskaya (2004) aptly called them. They also appear in those elements that are undergoing changes in Russia, too, e.g., replacement of declensions by prepositional phrases. Together they create synergy, cross-feeding the language and culture, and serving as adhesives in Russian-language networks.

In India, Japan and Korea Russian has no legal status but its functional status has become more solid thanks to the growing number of businesses, social and cultural institutions immigrants have created in which Russian is spoken. Language has been long regarded as an essential element of migrants' social capital. When the prevailing model guiding immigrant integration policies was linguistic and cultural assimilation, what counted was immigrants' acquisition of the language of the majority (Chiswick 2008). Native language maintenance was not viewed as important for socio-economic mobility. It was considered primarily in terms of symbolic functions of language manifested in the desire to pass on heritage culture to the young and preserve intergenerational ties. But due to a rapid expansion of service industries and emergence of vibrant Russian-speaking communities in many countries, Russian turned into an economic resource, helping migrants from the FSU to find jobs and open their own businesses. These businesses are diverse and are not limited to the traditional immigrant businesses of food stores, ethnic restaurants and craft shops but, as our research shows, include language centers, schools, travel agencies, law firms, agencies organizing trade with the FSU countries, and others.

As India and Russia continue their diplomatic relations in the $21^{\text {st }}$ century with vigor and seek to open new avenues of cooperation, the role of Russian language is likely to increase. The signing of the "Declaration on the India-Russia Strategic Partnership" in October 2000, later elevated to the level of "Special and Privileged Strategic Partnership," has given a new impetus to India-Russia ties with enhanced levels of cooperation in almost all areas of the bilateral relationship, including political, security, defense, trade and economy, science and technology, and culture (ENA, May 20m 2021) ${ }^{10}$. Many exchange programs and memoranda of

${ }^{10}$ https://indianembassy-moscow.gov.in/index.php (accessed 18 November 2021). 
understanding between universities are already underway, leading to an increasing interest amongst Indians in the Russian language, literature and culture. More and more young Russian entrepreneurs and other professionals are working in India. A study of changing patterns in their use of the mother tongue can be a source of further research on language diversity and multilingualism.

In the past, Russian and Soviet relations with Japan and South Korea alternated between periods of political and military hostility, and mutual cultural or commercial interest; this is still reflected in the language and social attitudes of the Japanese and Koreans towards Russia. Old waves of Russian immigration contributed to the cultural life of Japan and introduced the Orthodox Church in Korea. For some migrants, Japan was a stepping-stone on the way to the U.S.A. or Australia. South Korea is attractive for repatriates (Russian Koreans), students, entrepreneurs and workers from the Central Asian States and the Russian Far East. The influence of Russian culture on Japan and vice versa is multilayered and versatile, ranging from food and clothes to science and politics. Russian literature and music are popular in Japan and South Korea, and many universities offer courses of Russian. The recent post-Soviet diaspora is rapidly growing. The intensification of Russian tourism and the emergence of new Russian-owned businesses contribute to the economic value of the Russian language.

Russia positions itself as one of the key players in Asia, and there are traditional and newly restructured ties that allow alliance-building based on mutual interests in this part of the world. Universities and schools are trying to establish networks that would lead to joint projects and exchanges. There is no direct evidence that would allow us to suggest that there is ample linguistic data distinguishing the use of the Russian language by the diasporans residing in India, Japan and Korea and by learners of Russian as a foreign language in these countries.

The Russkiy Mir Foundation aims to promote different cultural projects, especially musical ones, in South Korea, Japan, and other Asian countries. It invites leading university scholars to visit Russia and sends artists to these countries (Russkiy Mir 2017, 2018). The Russian authorities are interested in the export of educational services, but they underestimate the necessity to adapt language teaching methodologies to local contexts. Teaching materials they offer do not take into account regional varieties of language or different linguistic biographies of heritage language learners inevitable in multilingual contexts (Ferreira 2012). Russian schools at the embassies offer courses and examinations. Students are invited to study in Russia because the quality of teaching is high and costs are low. Energy, aviation, exploration of new technologies, space research, the Silk Road Economic Belt, and the Eurasian Economic Community need collaboration in this part of the world (Bobylo 2016). Russian citizens are turning to Asia more often than before, and with modern technologies people can make online connections from any part of the world. One can anticipate that after the COVID-19 pandemic online teaching will keep developing. 


\section{Conclusions}

Evidently, globalization, diversification and increasing role of niche markets, as well as growing mobility of people belonging to different social classes and age groups is changing the role of language in economies. A special role in the increasing value of languages is played by the ubiquity of digital technologies. Besides occupational skills, people seeking employment in service industries and as white collars are required to have communicative skills, quite often in two or more languages. These new opportunities and new needs increase motivation for learning and maintaining the Russian language in the diaspora. Different social layers and ethno-cultural groups within the diaspora, sociolinguistic constraints on the use of the language, adaptation of the immigrants' language and culture to the surrounding society influence the diversity of the local discourse and contribute to the flexibility of the global discourse.

In all countries discussed, the Russian language is undergoing changes under the influence of contact with other languages. Most noticeable these deviations are on the lexical level. Regional varieties of Russian integrate lexis related to the local toponymy, flora, fauna and climate, foods, elements of traditional culture and festive traditions. In the contact situations of India, Japan and Korea, we see many words from local languages which are still exoticisms, that is why, after using them, speakers or writers often add translation or explanations. Equally strong in these countries is borrowing from the domains of government and administration. Notably, in all samples of the material we collected, we see integration of English lexis. The spread and universalization of education, the struggle for resources, frequent migrations with different goals and at different stages of life influence language contacts as never before. Scientific and technological progress as well as politics cause changes in all languages as part of a response to the spread of multilingualism on a global scale.

From the Russo-centric perspective, we can claim that Russian is a world language experiencing pluricentric development, having different variants in every country where it is used, but so are other languages in diasporas. We are convinced that a pluricentric approach to the study of Russian outside the nation is fruitful because it enables researchers to observe development of the language in new contexts and have a better understanding of its interaction with other languages and cultures. Russian pluricentricity needs to be thoroughly documented before a handbook of World Russians can be compiled. When communities of practice start using the language for their own purposes, it develops into a variant that will serve the specific needs of specific societies with distinctive cultures.

(C) Ekaterina Protassova, Neelakshi Suryanarayan and Maria Yelenevskaya, 2021

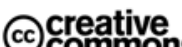

This work is licensed under a Creative Commons Attribution 4.0 International License https://creativecommons.org/licenses/by/4.0/ 


\section{Acknowledgements}

We would like to express our gratitude to the anonymous reviewers of this article. Their constructive criticism pointed to some weaknesses of the original text and facilitated its revision.

\section{REFERENCES}

Arefyev, Aleksandr L. 2012. Russian Language at the turn of XX-XXI centuries. Moscow: Center for Social Forecasting and Marketing. (In Russ.)

Avakiants, Galina. 1995. Teaching Russian in Japan (ethno-sketch). Hitotsubashi Journal of Social Studies 27 (1). 27-32.

Ballod, Janna O. 2009. The current problems of teaching Russian language in South Korea today. RUDN Journal of Language Education and Translingual Practices 4. 31-35.

Barman, Elena. 2015. About working upon the spread of Russian language in India. The International Affairs 25.10. URL: interaffairs.ru/news/show/13989 (In Russ.)

Baxter, James C. (ed.). 2009. Interpretations of Japanese Culture: Views from Russia and Japan. Kyoto: International Research Center for Japanese Studies.

Bazhanov, Eugene \& Natasha Bazhanova. 1991. Soviet views on North Korea: The domestic scene and foreign policy. Asian Survey 31 (12). 1123-1138.

Bobylo, Andrej M. 2016. Russian education development strategy as a factor of Russia's national interests in Asia-Pacific Region. PACIFIC RIM: Economics, Politics, Law 3. 3954.

Bowen, Glenn A. 2009. Document analysis as a qualitative research method. Qualitative Research Journal 9 (2). 27-40.

Burgess, Stephen F. 2019. Russia, South Asia, and the United States: A new great game? Journal of Indo-Pacific Affairs 2 (3). 8-32.

Chiswick, Barry R. 2008. The economics of language: An introduction and overview. IZA Discussion Papers, No. 3568. 1-29. Bonn: Institute for the Study of Labor (IZA). URL: nbn-resolving.de/urn:nbn:de:101:1-2008070230 (accessed 18 November 2021).

Corbin, Juliet \& Anselm Strauss. 2015. Basics of Qualitative Research: Techniques and Procedures for Developing Grounded Theory 4th ed. Thousand Oaks, CA: Sage.

Deponian, Karine G. 2015. Russian as a foreign language in South Korea: The role of native language in materials' selection. Humanities, Social-Economic and Social Sciences 2 (3). 212-216.

Dey, Sajal. 2015. Birth of a discipline: The case of Russian studies in India. Russkii Yazyk za Rubezhom 4. 98-102.

Emigrating. 2020. Statistics of emigration from Russia. 21.03. URL: emigrating.ru/statistikaemigratsii-iz-rossii (In Russ.)

Gasparov, Boris M. \& Natalia A. Kupina (eds.). 2014. Russian Language in the Multilingual Multicultural Space. Yekaterinburg: Ural Federal University.

Glovinskaya, Marina Ya. 2004. The general types of changes in the first generation of the Russian emigration language. In Mustajoki \& Protassova (eds.). 13-20. (In Russ.)

Golovina, Ksenia. 2018. Russian migrants in Japan and their Japanese homes. Issues of Japanology 7. 588-601.

Golovina, Ksenia. 2019. Daruma meets Domovoi and then some yoga: Russians in Japan and the religious-spiritual materiality of migrant living. Japanese Religions 43 (1\&2). $145-167$.

Hino, Nobuyuki. 2020. English as a Lingua Franca from an applied linguistics perspective: In the context of Japan. Russian Journal of Linguistics 24 (3). 633-648. 
Hoon, Shim J. 1993. South Korea: The Russian roulette. Far Eastern Economic Review 156 (40). 30.

Kazakevich, Maria. 2013. Russian language in the Russian-speaking diaspora in Japan. Problemy Prepodavaniya Russkogo Yazyka 4. 75-96. (In Russ.)

Khisamutdinov, Amir A. 2013. Russian Waves in the Pacific: From Russia to the New World via China, Korea and Japan. Beijing: Rubezh. (In Russ.)

Kidera, Ricuko. 2017. Cultivating interest in the Russian language and literature in Japan. Vysshee Obrazovanie dlya XXI Veka: Problem Vospitaniya, 544-549. Moscow: Moscow Humanitarian University. (In Russ.)

Kim, Dokdzhun. 2012. Russian influence on North Korea: Views of former South Korean ambassadors to Russia. The Korean Journal of Defense Analysis 24 (3). 391-404.

Kirichenko, Maria A. 2020. Japanese education: Distance learning and other challenges of the present. East Asia: Facts and Analytics 2. 51-65.

Konishi, Sho. 2013. Anarchist Modernity: Cooperatism and Japanese-Russian Intellectual Relations in Modern Japan. Cambridge, Mass.: Harvard University Asia Center.

Korgun, Irina A. 2014. About migration of Russians into Republic of Korea. In Ivan A. Solov'ev (ed.), Migration Processes and Migrants' Integration in Russia, 61-64. Stavropol': SKFU.

Kuhrt, Natasha C. 2007. Russian Policy towards China and Japan: The El'tsin and Putin Periods. London: Routledge.

Kuhrt, Natasha C. 2015. Russia and Asia-Pacific: Diversification or Sinocentrism? In David Cadier \& Margot Light (eds.), Russia's Foreign Policy: Ideas, Domestic Politics and External Relations, 175-189. Basingstoke: Palgrave Macmillan.

Kuhrt, Natasha C. \& Yulia Kiseleva. 2017. Russia-India Relations: Strategic partnership put to the test? In Donette Murray \& David Brown (eds.), Power Relations in the Twenty-first Century: Mapping a Multipolar World, 157-173. London: Routledge.

Kuroiwa, Yukiko. 2011. Northern challenges: The Japan-Russian border dispute and local voices. Journal of Borderlands Studies 26 (3). 283-295.

Lan'kov, Andrej. 2016. The train with Dostoevsky dashes through the snow. Lenta.ru. 11.1. URL: lenta.ru/articles/2016/01/11/koreanslovesrussia (accessed 18 November 2021).

Lim, Susanna S. 2013. China and Japan in the Russian Imagination, 1682-1922: To the Ends of the Orient. London: Routledge.

Mikhailova, Yulia \& M. William Steele (eds.). 2008. Japan and Russia: Three Centuries of Mutual Images. Folkestone: Global Oriental.

Min, Kön-Hön, Elena V. Katyshevceva, L. I. Katyshevceva \& Andrej V. Lebedev. 2018. Historical aspects of the linguistic security of the Russian language: Based on materials of the Russian historical school of the Korö University (South Korea). In Maria A. Vikulina (ed.), Language Policy and Linguistic Security, 303-317. Nizhny Novgorod: Linguistics University of Nizhny Novgorod.

MVD 2020. Ministery of Inner Affairs. Statistics of the migration situation. URL: xn--b1aew.xn--p1ai/Deljatelnost/statistics/migracionnaya (In Russ.)

Musaev, Davron \& Kajgaj Boeki Tojama. 2014. Russian immigration in Japan: Russian business. In Ivan A. Solov'ev (ed.), Migracionnye Processy v Rossii: Problemy Adaptacii i Integracii Migrantov, 57-60. Stavropol': SKFU. (In Russ.)

Mustajoki, Arto \& Ekaterina Protassova (eds.). 2004. A Russian-Speaking Person in a ForeignLanguage Environment. Helsinki: University of Helsinki. (In Russ.)

Mustajoki, Arto, Ekaterina Protassova \& Maria Yelenevskaya (eds.). 2019. The Soft Power of the Russian Language: Pluricentricity, Politics and Policies. London: Routledge.

Mustajoki, Arto, Ekaterina Protassova \& Nikolai Vakhtin (eds.). 2010. Instrumentarium of Linguistics: Sociolinguistic Approaches to Non-Standard Russian. Helsinki: University of Helsinki. 
Muth, Sebastian \& Neelakshi Suryanarayan. 2020. Language, medical tourism and the enterprising self. Multilingua 39 (3). 321-342.

Nakamura, Yosikadzu. 2003. About Russistics in Japan. Russkiy Yazyk za Rubezhom 3. 114-117. (In Russ.)

Nagatsuka, Hideo (ed.). 2014, 2017. 30 Unique Figures of Japan and Russia. People Who Have Made Great Contribution to the Establishment of Exchange and Mutual Understanding between the Two Countries. Tokyo: Seikatsu jānaru.

Nikiporec, Galina. 2007. Russian diaspora in Japan: History, problems of existence and maintenance of the Russian language. Acta Linguistica 1. 75-83.

Nikiporec-Takigava, Galina Y. 2007. The Russian diaspora in Japan through the prism of linguistic competence. Diaspory 9 (1-2). 83-109.

Nikiporec-Takigava, Galina Y. 2011. Contemporary Russian diaspora in Japan. In Viktorija V. Krasnyh (ed.), Russian Language under Conditions of Linguisitic and Cultural Polyphony, 158-168. Moscow: Azbukovnik.

Nikunlassi, Ahti \& Ekaterina Protassova (eds.). 2014. Russian Language Tools: Errors and Multilingualism. Helsinki: University of Helsinki. (In Russ.)

Nikunlassi, Ahti \& Ekaterina Protassova (eds.). 2019. Russian Language in the Multilingual World. Helsinki: University of Helsinki.

Oglezneva, Elena A. 2009. The Russian Language in the Eastern Countries (On the Material of Russian Language in Harbin). Blagoveshchensk: Amur State University.

Pajchadze, Svetlana A. 2008. On the centers of the Russian book culture in Japan. Istoriya $i$ Kul'tura Priamur'ya 1 (3). 174-179. (In Russ.)

Pajchadze, Svetlana A., Takeda, Elena V. \& Savinykh, Anna S. (eds.). 2021. Collection of Conference Materials on Teaching Russian as the Native, Heritage and Foreign Language in Japan. Hokkaido: Hokkaido University.

Park, Hyun Gwi. 2018. The Displacement of Borders among Russian Koreans in Northeast Asia. Amsterdam: Amsterdam University Press.

Pavlenko, Aneta (ed.). 2008. Multilingualism in Post-Soviet Countries. Clevedon: Multilingual Matters.

Podalko, Pjotr. 2019. Russians in Japan: “Three waves" of building, courage, creation. Russian Historical Society 14.01. URL: historyrussia.org/tsekh-istorikov/russkie-v-yaponii-trivolny-sozidaniya-muzhestva-tvorchestva.html (accessed 18 November 2021).

Proshina, Zoya G. \& Cecil L. Nelson. 2020. Varieties of English and Kachru's expanding circle. Russian Journal of Linguistics 24 (3). 523-550.

Protassova, Ekaterina \& Maria Yelenevskaya. 2021. Stable/variable Russian, its standardisation and pluricentrism. In Christian U. Noack (ed.), Politics of the Russian Language beyond Russia - Russian Language and Society, 187-214. Edinburgh: Edinburgh University Press.

Protassova, Ekaterina, Maria Yelenevskaya \& Johanna Virkkula. 2020. Old and new homes of the Russian language in Europe. RussianStudies.hu.

Rapley, Tim. 2007. Doing Conversation, Discourse and Document Analysis. London: Sage.

Rinna, Anthony V. 2019. Moscow's “turn to the East” and challenges to Russia-South Korea economic collaboration under the New Northern Policy. Journal of Eurasian Studies 10 (2). 159-168.

Rishi, Weer R. 1982. India \& Russia: Linguistic and Cultural Affinity. Chandigarh: Roma Publications.

Rosstat 2019. Statistics of migration derived from the data of the Russian Bureau of Statistics. URL: rosinfostat.ru/migratsia/\#i-8. (In Russ.)

Rovinskaya, Maria M. (ed.). 2013. Russian Language Abroad. St. Petersburg: Zlatoust.

Russian 2018. Ethnologue. Languages of the World. URL: ethnologue.com/language/rus. 
Russistics in Japan. 2016. [Special issue]. Russian Language Abroad. URL: pushkin.institute/ science/publikacii/RYAZR_Yaponiya.pdf (accessed 18 November 2021).

Russistics of South Korea. 2016. [Special issue]. Russian Language Abroad. URL: pushkin.institute/science/russkiy_yazyk_za_rubezhom/\%D0\%AE\%D0\%B6\%D0\%BD $\%$ D0\%B0\%D1\%8F\%20\%D0\%BA\%D0\%BE\%D1\%80\%D0\%B5\%D1\%8F-\%D0\%92\% D0\%B5\%D1\%80\%D1\%81\%D1\%82\%D0\%BA\%D0\%B0.pdf (accessed 18 November 2021).

Russkiy Mir. 2017. Korean society of Russian language and literature teachers celebrated 30th anniversary. 15.06. URL: russkiymir.ru/en/news/226040 (accessed 18 November 2021).

Russkiy Mir. 2018. Russkiy Mir Foundation intends to promote Russian language and culture in Japan. 11.12. URL: russkiymir.ru/en/news/249888 (accessed 18 November 2021).

Ryazanova-Clarke, Lara (ed.). 2014. The Russian Language Outside the Nation. Edinburgh: Edinburgh University Press.

Sahai, Shrinath. 1990. The Delhi Declaration: Cardinal of Indo-Soviet Relations. New Delhi: Mittal.

Saini, Sonu. 2017. Modern Russian teaching techniques and advancement of Russian language teaching in India. In Elena V. Voronova, Natalia G. Naumova \& Julia V. Igoshina (eds.), Sovremennye Tekhnologii Obucheniya Russkomu kak Inostrannomu, 36-44. Kirov: Vyatskii gosudarstvennyi universitet. (In Russ.)

Savada, Kadzuhiko. 1999. Russkie v Yaponii (1917-1945). Rossiyane v Azii. 6. 237-269. (In Russ.)

Shatokhina, Ganna. 2012. Russian language for children in Japan. Mir Russkogo Slova 3. 106-109.

Shlapentokh, Dmitry. 2012. Afanasy Nikitin's Voyage Beyond Three Seas: An Orthodox Russian in medieval India. Oriens 40 (1). 169-190.

Sindzi, Yekote. 2005. Soviet riddles for the Japanese elite: Perception of the Japanese statesmen and politicians of Russia in the 1920s-1930s. Rodina 10. 27-31. (In Russ.)

Sivakova, Stella V. 2009. Problems of teaching Russian to bilingual and migrant children in Japan. Russkii Yazyk za Rubezhom 6. 116-122.

Sunita, Tanwar, Renu Mital, Tat'jana M. Balykhina, \& Tat'jana E. Perova. 2012. Conception of basic national-oriented textbook on practical course of Russian language for schools of India. Vestnik RUDN, Seriya Voprosy Obrazovaniya: Yazyk I Spetsial'nost' 1. 117-125. (In Russ.)

Suryanarayan, Neelakshi. 2014. Teaching Russian language in India: The most typical errors of the Indian students. In Nikunlassi \& Protassova (eds.), 50-62. (In Russ.)

Suryanarayan, Neelakshi. 2017a. From Yashwant Place to Yashka: A case study of commodification of Russian in India. International Journal of Bilingual Education and Bilingualism 20 (4). 428-442.

Suryanarayan, Neelakshi. 2017b. The role of the Russian language in India's health care. Russian Journal of Linguistics 21 (3). 515-529.

Thakur, Subhash K. 2017. Russistics in India: Past, present and future. In Elena Y. Titarenko (ed.), Russkii Yazyk v Poliul'turnom Mire, 229-235. Simferopol: Vernadsky Crimea Federal University. (In Russ.)

Wells, David N. 2004. Russian Views of Japan, 1792-1913: An Anthology of Travel Writing. London: Routledge.

Yamasita, Marico. 2010. Russian language in Japan. The first Russian-Japanese contacts. The World of Russian Word 4. 92-96.

Yelenevskaya, Maria \& Ekaterina Protassova (eds.). 2015. Global Russian: Between decline and revitalization. [Special issue]. The Russian Journal of Communication 7 (2). 
Article history:

Received: 20 May 2021

Accepted: 19 October 2021

\section{Bionotes:}

Ekaterina PROTASSOVA holds PhD in Philology and Hab. in Pedagogy. She is Adjunct Professor at the Department of Languages at the University of Helsinki. She has over 300 scholarly publications. Dr Protassova headed and participated in various international and national projects investigating language pedagogies, child and adult bilingualism, and the role of language and culture in immigrant integration. Her service to the profession includes editorial work for various journals and publishers and organization of seminars and conference panels.

\section{Contact information:}

Department of Languages, PL 24, 00014 University of Helsinki, Finland e-mail: ekaterina.protassova@helsinki.fi

ORCID: 0000-0002-8271-4909

Neelakshi SURYANARAYAN is Dr, Professor, affiliated with the Department of Slavonic and Finno-Ugrian Studies, University of Delhi, India. She has been teaching the Russian language, literature, and culture. Her research interests include commodification of the Russian language in the $21^{\text {st }}$ century and comparative study of speech etiquette. She regularly participates in conferences and publishes nationally as well as internationally in well-known journals. Neelakshi Suryanarayan has received several awards and certificates of merit for her active contribution in promotion of Russian Studies in India.

\section{Contact information:}

A 26, Sector 44, Noida, 201301, India

e-mail:neelakshi55@yahoo.co.in

ORCID: 0000-0002-6657-2533

Maria YELENEVSKAYA (PhD) is affiliated with the Department of Humanities and Arts at the Technion-Israel Institute of Technology. Throughout her pedagogical career she has developed teaching and testing materials for EAP courses, including multimedia modules for computer-assisted language learning. Her research is devoted to language in multilingual and multicultural settings, lingua-cultural aspects of immigration, computerassisted language learning and lingua-cultural aspects of humour. She has over 70 scholarly publications. She serves on the editorial board of three international scholarly journals and is a board member of Israel Association for the Study of Language and Society.

\section{Contact information:}

Technion-Israel Institute of Technology

Technion City, 3200003 Haifa, Israel

e-mail:ymaria@technion.ac.il

ORCID: 0000-0001-7155-8755 


\section{Сведения об авторах:}

Екатерина ПРОТАСОВА - кандидат филологических и доктор педагогических наук, адъюнкт-профессор Отделения языков Хельсинкского университета. Она опубликовала более 300 научных трудов, возглавляла и принимала участие в многочисленных национальных и международных научных проектах, посвященных преподаванию языков, детскому и взрослому билингвизму, а также роли языка и культуры в интеграции иммигрантов. Ее профессиональная деятельность включает редактирование и рецензирование для различных научных журналов и издательств, а также организацию научных семинаров и секций на международных конференциях.

\section{Контактная информация:}

Department of Languages, PL 24, 00014 University of Helsinki, Finland e-mail: ekaterina.protassova@helsinki.fi

ORCID: 0000-0002-8271-4909

Нилакши СУРЬЯНАРАЯН - доктор, профессор кафедры славянских и финноугорских исследований Делийского университета. Преподавала русский язык, литературу и культуру. Ее исследовательские интересы включают коммодификацию русского языка в XXI веке и сопоставительное исследование речевого этикета. Профессор Сурьянарьян регулярно участвует в конференциях и публикует статьи на национальном и международном уровне в высокорейтинговых журналах. За активный вклад в развитие русистики в Индии она получила несколько наград и грамот.

\section{Контактная информация:}

A 26, Sector 44, Noida, 201301, India

e-mail:neelakshi55@yahoo.co.in

ORCID: 0000-0002-6657-2533

Мария ЕЛЕНЕВСКАЯ - кандидат филологических наук, работает на кафедре гуманитарных наук Техниона - Политехнического института Израиля. На протяжении всей педагогической карьеры она разрабатывает учебные пособия, тесты и мультимедийные модули для компьютеризированного обучения языкам. Ее исследования посвящены функционированию языка в многоязычном и многокультурном пространстве, лингвокультурным аспектам иммиграции, использованию компьютерных технологий в обучении языкам и лингвокультурным аспектам юмора. Она является членом редколлегий трех международных журналов и членом правления Израильской ассоциации исследования языка и общества.

\section{Контактная информация:}

Technion-Israel Institute of Technology

Technion City, 3200003 Haifa, Israel

e-mail:ymaria@technion.ac.il

ORCID: 0000-0001-7155-8755 